\title{
TITLE:
}

\section{完成後の盤ぶくれを防ぐ新たなイ ンバートの抑制効果}

\author{
$\operatorname{AUTHOR}(\mathrm{S}):$ \\ 小林, 寛明; 上野, 光; 磯谷, 篤実; 嶋本, 敬介; 岸田, 潔
}

\section{CITATION:}

小林, 寛明 ...[et al]. 完成後の盤ぶくれを防ぐ新たなインバートの抑制効 果. 土木学会論文集F1 (トンネル工学) 2019, 75(1): 116-129

ISSUE DATE:

2019-10

URL:

http://hdl.handle.net/2433/245342

RIGHT:

(C) 2019 公益社団法人土木学会 


\section{完成後の盤ぶくれを防ぐ 新たなインバートの抑制効果}

\section{小林 寛明 1 ・上野 光 ${ }^{2}$ 磯谷 篤実 3 ・嶋本 敬介 4 ・岸田 潔 5}

1正会員 (独)鉄道建設・運輸施設整備支援機構 東京支社（干 105-0011 港区芝公園2-4-1）

E-mail: kobayashi.hir-4k55@jrtt.go.jp

2(独)鉄道建設・運輸施設整備支援機構 大阪支社（干532-0003 大阪市淀川区宮原3-5-36）

E-mail: ueno.hik-7c7u@jrtt.go.jp

3正会員 (独)鉄道建設・運輸施設整備支援機構 本社（干231-8315 神奈川県横浜市中区本町6-50-1）

E-mail: isogai.ats-26es@jrtt.go.jp

4正会員 (公財)鉄道総合技術研究所 防災技術研究部（率185-8540 国分寺市光町2-8-38）

E-mail: shimamoto.keisuke.00@rtri.or.jp

5 正会員 京都大学大学院教授 工学研究科都市社会工学専攻（†615-8540 京都市西京区京都大学桂）

E-mail: kishida.kiyoshi.3r@kyoto-u.ac.jp

近年，山岳トンネルにおいて完成後に盤ぶくれが発生し，対策を実施した事例が報告されているが，鉄 道などの走行安全性を確保するためには, 盤ぶくれを未然に防ぐことは非常に重要である. しかし, 掘削 時の地山状況から盤ぶくれがわずかでも懸念される地山に対して，曲率が大きいインバートや鉄筋コンク リート構造のインバートを採用することは，現実的ではない。本研究では，これらの課題の解決をすべく 新たに整備新幹線の山岳トンネルで採用されているインバート構造1)を対象に模型実験と数值解析を行い, 盤ぶくれの挙動を把握するとともに，標準的なインバート構造と比較し盤ぶくれの抑制効果について検証 を行った。その結果, 新たなインバート構造は施工性, 経済性は従来の構造と同程度でありながら, 盤ぶ くれ抑制効果が向上することを確認した。

Key Words : mountain tunnel, invert, floor heaving, model test, numerical analysis

\section{1. はじめに}

近年，完成後の山岳トンネルにおいて盤ぶくれが発生 し, インバートの改築工事を行った事例2),3)や下向きロッ クボルトなどによる盤ぶくれの抑止対策工事を行った事 例4)が報告され，山岳トンネルにおける盤ぶくれ防止は 重要な課題となっている．筆者らは，山岳トンネルにお ける盤ぶくれ事象に関して，これまで，過去の事例を分 析実施し, 完成後に盤ぶくれが発生しや寸い地質的な条 件を整理するとともに，その中で明らかになった，地山 の吸水劣化が盤ぶくれの発生の原因になることを模型実 験と数值解析で明らかにした5)。また，実際に盤ぶくれ が発生したトンネルの事例を取り上げ，地質的な特徵と 掘削時の状況から，完成後に盤ぶくれが顕在化する背景 について考察した．さらにインバートによる掘削時およ び完成後の盤ぶくれの抑制効果を検証するために，イン バート形状と支保工をパラメータとした数值解析を実施
した. その結果, 早期閉合と曲率の大きいインバートが, 地山の塑性領域の拡大を抑制し, 完成後の盤ぶくれに効 果的であることを示したの). また，盤ぶくれ発生後の対 策工としてロックボルトを取り上げ，その効果について 研究を実施してきた例えばフ,8).

日本の地質は変化に富んでいることや，事前の調査に は限界があること等から，建設時における検討により盤 ぶくれを完全に防止することが難しく，これまでは，日 常の維持管理において盤ぶくれの兆候を早期に発見し, ロックボルトやインバートの追加・改築等を適宜実施す ることにより，トンネルの安全性を確保してきた. しか し, 盤ぶくれを防ぐための最も基本的な構造はインバー トであり，建設時において適切な構造のインバートを設 置することにより，盤ぶくれを未然に防止することが重 要であると考えている. 


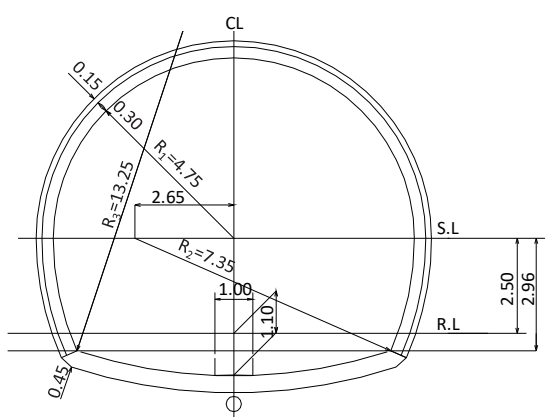

(a) $\mathrm{I}_{\mathrm{NiP}}$

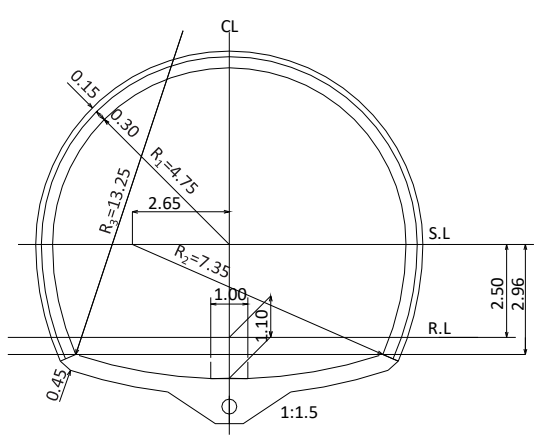

(b) $\mathrm{I}_{\mathrm{NAiP}}$

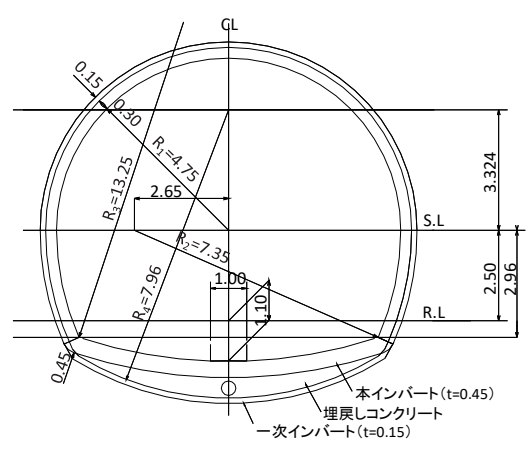

(c) IsiP

図-1 新幹線の山岳トンネルにおけるインバート構造

\section{（1）インバートの設置基準}

鉄道トンネルでは，矢板工法の時代より，地質が不良 な地山ではインバート設置の必要性が示され例えば9), 数多 く施工されてきた. その後，1983 年に制定された NATM 設計施工指針（案）10)において，インバートの設置基準 は地山等級により区分されて示されるようになり，地山 等級が $I_{N}$ 以下に該当する地山においてはインバート（図 -1(a), 以下， $\mathrm{I}_{\mathrm{NiP}}$ と呼ぶ）を設置するように定められた. しかしその後, 地山等級が $\Pi_{\mathrm{N}}$ より良いと判断され，イ ンバートが設置されていなかった北陸新幹線碓水䟔トン

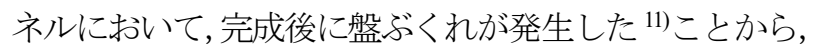
2008 年に制定された，山岳トンネル設計施工標準・同解

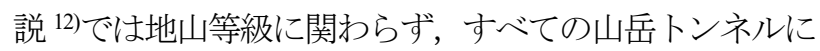
おいてインバートを施工するように改められ，その後， 盤ぶくれの事例は減少した.

高速道路トンネルにおいても，地山等級 DI，DII，E は原則としてインバートの設置が必要とされ，地山等級 CI，CII においても，地質が泥岩，凝死岩，蛇紋岩等の 粘性土岩や風化結晶片岩, 温泉余土等, 劣化が予想され る地質においては，インバートの設置が必要とされてい る ${ }^{13)}$.このように，盤ぶくれを防止するためのインバー トの設置については各機関において重要性がすでに認識 されてきている.

\section{(2) 新たなインバート構造}

2012 年に北陸新幹線の峰山トンネルにおいて, インバ ートを設置していたにも関わらず，インバート完成後に 盤ぶくれが発生し，対策工の施工を余儀なくされた事象 が発生した ${ }^{6}$ 。これにともない，インバートの設置基準 と併せて, 構造についても見直しが行われた. 2014 年に は，盤ぶくれを抑制するために，新たなインバート構造 の $\mathrm{I}_{\mathrm{NAiP}}$ (図-1(b)）が示されるとともに，地質，地山強度 比 $\left(\mathrm{G}_{\mathrm{N}}\right)$, 浸水崩壊度などの地山物性值や内空変位量な どを指標としてインバート構造を選択するフロー1) (図-2, 以下,インバート設計施工フローといら)が定められた.
このフローは掘削時の状況から将来の盤ぶくれの可能性 を検討するものであるため，地山試料試験に十分な期間 が取れないことを想定し，試験項目を選定している．浸 水崩壊度については鉄道・運輸機構が定める試験方法 ${ }^{14)}$ により判定される，区分 3 または 4 を閾值としている. 区分 3 は浸水後 24 時間後の岩塊が細片化し, 部分的に泥 状化する状態を指し， 区分 4 は，完全に泥状化すること を指す。またスメクタイト含有量については，桜井ら ${ }^{15)}$ の手法によることとされている.

このフローに示される $\mathrm{I}_{\mathrm{NAiP}}$ は，中央集水管部を幅広く 掘削し，インバートコンクリートを中央集水管を抱き込 んで打設し, 中央集水管からインバート下の地山への水 の供給を抑えるとともに，相対的に弱点部である中央通 路部のコンクリートの巻厚を厚くした構造となっている. なお， $\mathrm{I}_{\text {NAiP }}$ が適用となるのは，泥質岩や凝灰岩類などの 軟岩地山で地山強度比が 2 以上で, 地山等級 $I_{\mathrm{N}}$ と判定さ れるものの, 浸水崩壊度が 3 以上の地山である.または, 地山強度比が 4 未満かつ膨張性粘土鉱物のスメクタイト 含有量が $20 \%$ 以上である地山であり，吸水による強度低 下や吸水膨張が懸念される箇所である.

\section{(3) 本論文の目的}

盤ぶくれを防止するためには，インバートの半径を小 さくすることやインバートの巻厚を大きくすることが効 果的であることは明らかである. しかし，インバートの 盤ぶくれ抑制効果を定量的に確認する手法は定められて おらず，インバートの半径や巻厚は経験的に定められて いることが多い. さらに，盤ぶくれが懸念される地山に おいては, 単にインバートを設置するだけにとどまらず, 地山条件を踏まえた上で，長期的な安定性の観点から最 適なインバート構造について，建設着手前に検討を行う ことが必要である.

インバートを扱ったこれまでの研究の多くは，掘削時 の内空変位量や近接構造物への影響の抑制などが主な研 究対象とされており，完成後のインバートの盤ぶくれ抑 


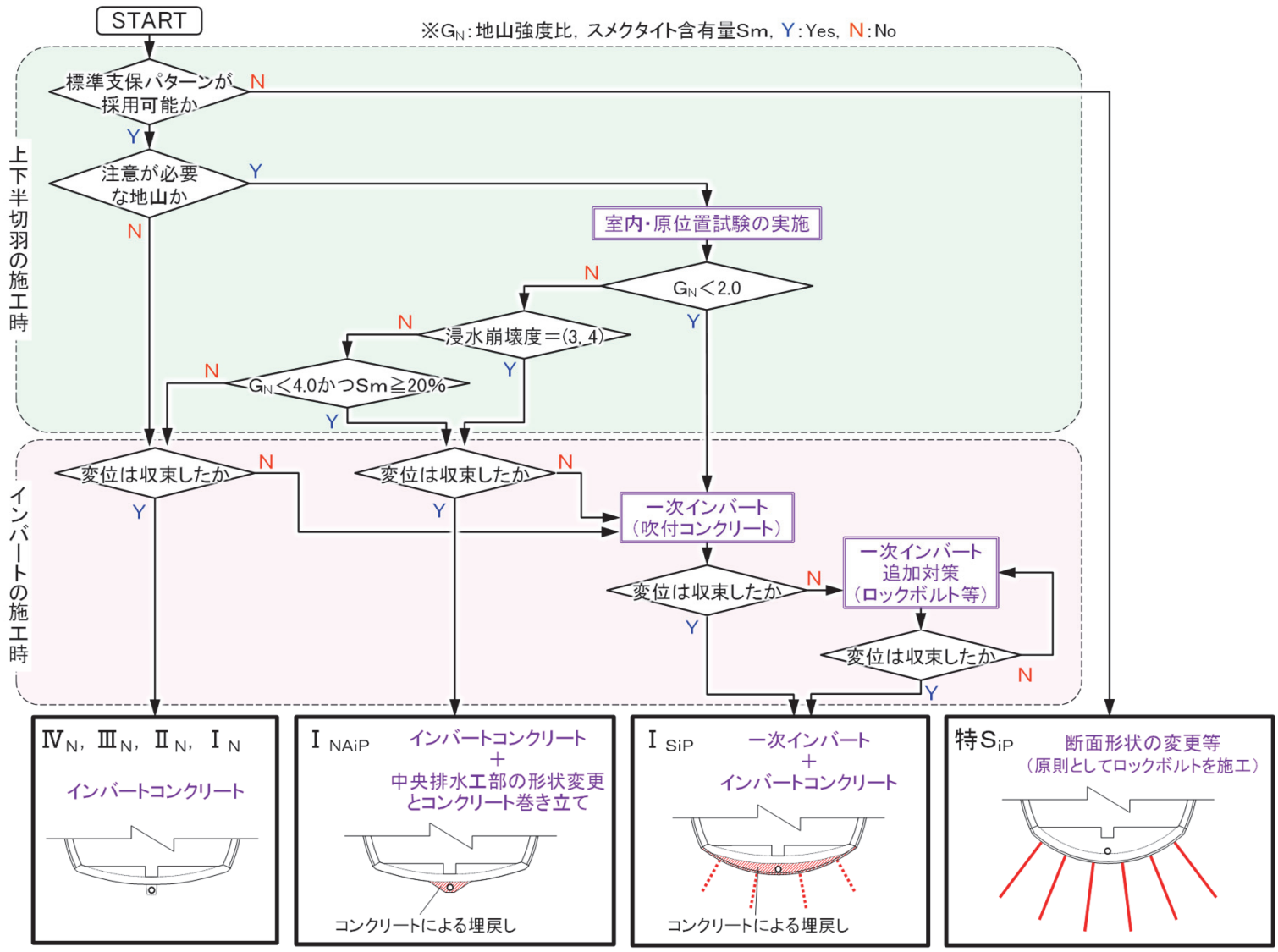

注）浸水崩壊度は鉄道・運輸機構の試験方法およひ判定基淮によること.

注）スメクタイト含有量試験については，鉄道技術研究報告（No.1312，付属資料1）を参照すること.

注）変位収束の判断は，本インバートを施工しようとする時期において，内空変位が $2 \mathrm{~mm} /$ 月程度を目安とする. ただし，一次インバートを 施工した場合は, 極力インバート部で計測を行い, その結果で判断寸ること.

図-2 インバート設計施工フロー（施工時）11飞追記

制を扱った研究はなされてこなかった. 筆者ら5),6はこれ まで，トンネル完成後の盤ぶくれを防止することを目的 として，長期的に吸水劣化する地山を対象とした模型実 験や数值解析を実施し, インバートの半径を小さくする ことで完成後の盤ぶくれを抑制できることを示した.イ ンバートの半径を小さくし，断面を円形に近づけること で，軸力が導入されやすい構造と寸ることにより，盤ぶ くれの可能性を減らせることは明白である. しかし，地 山条件が悪いトンネルにおいて, 例えば $\mathrm{I}_{\mathrm{SiP}}$ のような半 径の小さなインバートを施工するには，掘削に長い時間 が掛かり,トンネル周辺の地山の塑性域の拡大を助長し, 結果として内空変位量の増加や将来の盤ぶくれの可能性 を高めてしまう恐れも否定できない，そのため，掘削断 面積をむやみに大きくすることをせず，従来のインバー 卜と施工性に大きな差異が無く, その弱部を補強するこ とによって，より効果的に盤ぶくれを抑制できることが 望ましい.

本論文では，このような矁念に対して，新たなインバ 一ト構造である $\mathrm{I}_{\mathrm{NAiP}}$ を対象に, その盤ぶくれ抑制効果に
ついて, 模型実験と数值解析により検証を行った. 具体 的には, このインバート構造に対し, 新幹線断面を模擬 した模型を製作し，インバート下の地山を強制的に膨張 させることで, これまでの実験とは異なるメカニズムで インバートに盤ぶくれを生じさせ，インバートの破壊形 態を観察し, その特徴を把握するとともに, インバート の隆起量から， $\mathrm{I}_{\mathrm{NAiP}}$ の盤ぶくれ抑制効果を検証した。 ま たこれに加えて, 数值解析を実施し, 従来のインバート 構造と比較を行い，新たなインバート構造の盤ぶくれ抑 制効果を把握した.

\section{2. インバート構造による盤ぶくれ抑制の事例}

現在, 新幹線の山岳トンネルのインバートは, 地山が 良好で盤ぶくれのおそれがない場合でも, 半径 $13 \mathrm{~m}$ 程度, 巻厚 $30 \mathrm{~cm}$ または $45 \mathrm{~cm}$ の図-1(a)に示した標準的なイン バートが用いられている. 我が国で最初の NATM を対象 とした技術指針である文献 10)では，当時すでにインバ 
一トの厚さは $30 \mathrm{~cm}$ または $45 \mathrm{~cm}$ が示されており, 形状, 厚さ等は経験的に決められてきた. 道路においては, イ ンバートの形状は様々であるが，新幹線と同程度で半径 が 10〜20m の事例が多く, 上半の半径の 2 3 倍程度の

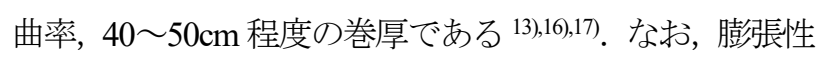
地山や早期閉合を要する地山の場合でも, 通常の地山と 同様なインバートとする例が多い，ただし，道路では新 幹線とは異なり，保守用通路が中央に無いため，掘削断 面を有効に利用するため, 中央集水管をインバートの内 側に設けている.

新幹線において，インバートがあるにもかかわらず完 成後に盤ぶくれが発生した過去の事例(何えば2)では, いずれ も $\mathrm{I}_{\mathrm{NiP}}$ が用いられており, 中央通路の底盤部や左右隅角 部に線路方向にひびわれが発生する変状形態となってい る.インバートは覆工と同様，円弧状とすることにより 軸力が導入されることが期待される. しかし， $\mathrm{I}_{\mathrm{NiP}}$ のイン バートの半径は, 覆工に比べて大きいことから, 特にコ ンクリートの厚さが薄くなる中央通路の底盤部において, 曲げモーメントに対する耐力が相対的に小さくなる．そ のため, インバートが地山から力を受けると, 中央通路 の底盤部にひび割れが入るものと考えられる.

インバートの半径を小さくして, 覆工の半径に近づけ ることにより, 軸力が導入されやすい構造となり, 曲げ モーメントに対する耐力を増加させることができると考 えられる，例えば，北陸新幹線飯山トンネルでは，建設 後（開業前）に盤ぶくれを生じたが，既設のインバート 下部の地山を掘削し，新たなインバートを既設のインバ 一トと一体となるように構築している. 新たに施工され たインバートは中央集水管の下部まで抱き込むような形 状をしており，半径 $6 \mathrm{~m}$ 程度となっている 2 .

山形自動車道盃山トンネルにおいては, 供用後に発生 した急激な盤ぶくれ対策として，既設のインバートを撤 去し, インバート下の地山を改めて掘削した後, 新たに 半径を $13.1 \mathrm{~m}$ から $10.0 \mathrm{~m}$ に変更し, 設計基準強度を $18 \mathrm{~N} / \mathrm{mm}^{2}$ から $24 \mathrm{~N} / \mathrm{mm}^{2}$ に上げたインバートを再施工し た ${ }^{18)}$. 上記のように，掘削中あるいはインバート構築後 に盤ぶくれが生じ, インバートの構造を変更する事例で は，時間的，施工的制約から，数值解析等により検討を 行う余裕がないことから，安全の裕度を見込み，十分な インバート半径, 巻厚を与えて, 経験的に設計を行って いる事例が多い，本来は，施工に着手する前の地質調査 などの結果から, 完成後の盤ぶくれ発生の可能性を判断 し，インバート構造の設計を行っておくことが望ましい が，そのような事例は多くない。これは，インバートを 扱った既往の研究の多くが，主に掘削時の早期閉合と関 連させ, 内空変位量の抑制や支保能力の向上に着目した もの例泣17)であることからもわかるように，インバート 構造がこれまで, 掘削時の内空変位量の抑制を主な目的
土木学会論文集F1 (トンネル工学), Vol. 75, No. 1, 116-129, 2019.

としていたこと，完成後の盤ぶくれを評価する手法が確 立されていなかったことなどが理由として考えられる.

\section{3. 模型実験}

\section{(1) 実験方法}

本稿では, 図-2 に示した整備新幹線の山岳トンネルで 採用されているインバート構造のうち $\mathrm{I}_{\mathrm{NAiP}}$ に着目し, 中 央通路部の補強による盤ぶくれ抑制効果の確認を目的と して，模型実験を行うこととした。ここで，模型実験に あたっては, 山岳トンネルの盤ぶくれを適切な方法で再 現する必要がある. 実験に先立ち, 完成後の盤ぶくれの メカニズムを以下のように整理した.

完成後の盤ぶくれの原因は, 直接的にはインバートに 作用する地山からの力によるものと考えられるが，嶋本 ら ${ }^{8)}$ によれば，完成後の盤ぶくれを生じさせる地山から の力の発生メカニズムとして, 図-3に示寸スクイージン グとスウェリングが考えられるとされており，スレーキ ングによる盤ぶくれ現象の再現 5をを行っている. また， スウェリングに対しては，嶋本ら〕が静的破䂗剂を混合 した低強度モルタルを模型トンネルのインバートの下に 配置し，これを膨張させる実験により，スウェリングに よる盤ぶくれの現象の再現を行っている.

実験により， $\mathrm{I}_{\text {NAiP }}$ の効果を検証するにあたっては，上 記のスクイージングによる盤ぶくれを再現する実験と, スウェリングにより再現する実験のどちらを行うかを決 める必要があるが，実験後にインバート中央部が最も隆 起寸る変形形態およびインバート内面側に線路方向の曲 げひび割れが発生する破壊の形態のいずれについても, どちらの実験でもほぼ同様に発生させることができるこ とが確認されていることから, 本研究で行う実験は, 後 者の静的破砕剂を混合した低強度モルタル（以下，膨張 モルタルという）を模型トンネルのインバートの下に配 置し，これを膨張させることでインバートと地山が相互 に作用しながら隆起が経時的に変化する実験を行うこと とした.

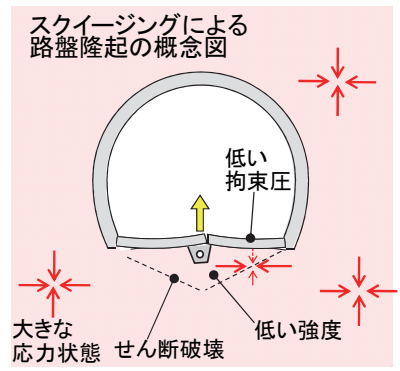

(a) スクイージング

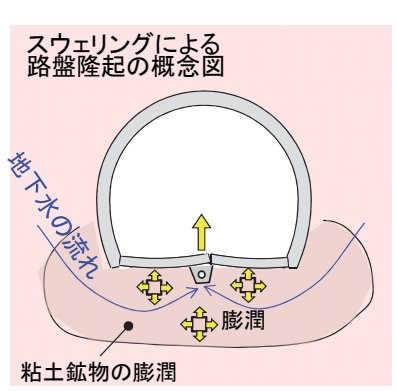

(b) スウェリング
図-3 想定される路盤隆起メカニズム ${ }^{8)}$ 


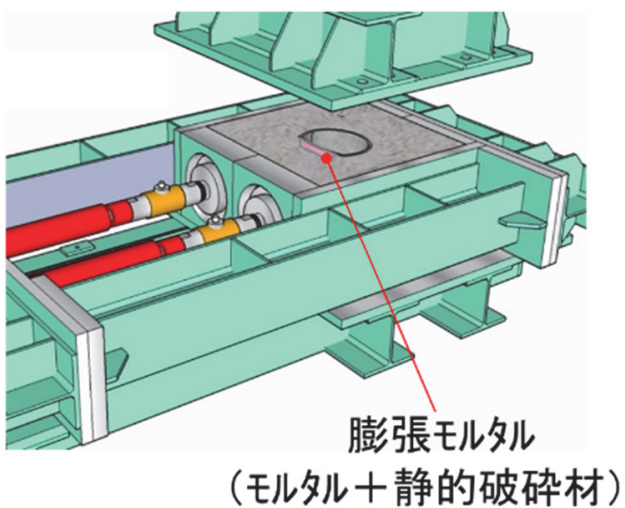

図-4 実験装置（全体）

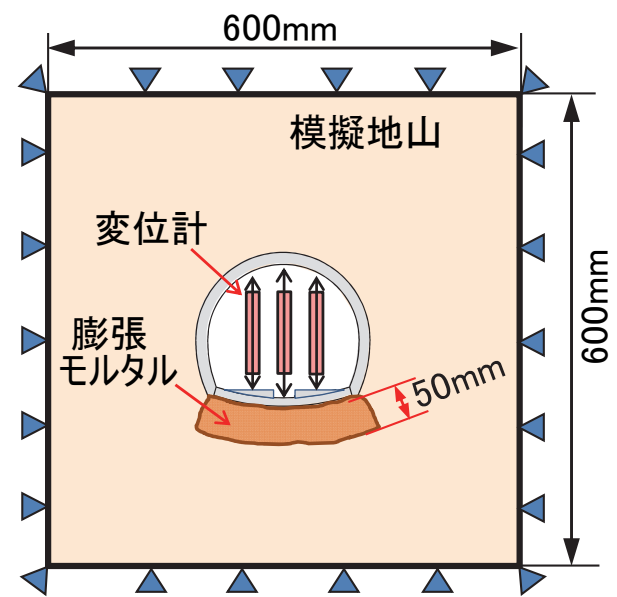

図-5 実験装置（断面図）

実験には，図-4，5 に示寸実験装置を使用した． $60 \mathrm{~cm}$ $\times 60 \mathrm{~cm} \times 30 \mathrm{~cm}$ （深さ）の土槽中に低強度モルタルで地 山を模擬し, 新幹線断面の $1 / 50$ スケールとなるモルタル 製のトンネル模型を鉛直方向がトンネルの線路方向に一 致するように設置した．インバート下には盤ぶくれを再 現するための膨張モルタルを配置し，計測を実施した.

覆工とインバートは別々に作製し, 覆工とインバート の接合部は剛結しないようにビニールテープを側壁脚部 に貼り，インバートと側壁脚部との隙間を低粘度のエポ キシ樹脂により充填した. 覆工とインバートに用いたモ ルタルの配合は既往の研究 5)を参考とし，表-1 に示寸配 合とした.

模擬地山に用いた低強度モルタルは過去の実験 5),19)を 参考に, 表-2のような配合とした. また膨張モルタルは, この低強度モルタルに静的破砕剂を質量比で $30 \%$ 混入し， 練り混ぜたものである ${ }^{20) . ~}$ 製作順序は土槽にトンネルの 模型を鈆直に配置し, 周囲に低強度モルタルを打設する. その際にインバート下には, ベークライト製のスペーサ 一を設置した。低強度モルタル打設 2 日後に，このスペ 一サーを引き抜き, その空間に膨張モルタルを打設する。 スペーサーの引き抜き状況を写真-1に示寸.
表-1 モルタルの配合 (トンネル模型)

\begin{tabular}{c|c|c}
\hline 材料 & 種類 & $\begin{array}{c}\text { 単位量 } \\
\left(\mathrm{kg} / \mathrm{m}^{3}\right)\end{array}$ \\
\hline 水 & - & 436 \\
\hline セメント & 普通ポルトランドセメント & 396 \\
\hline 細骨材 & 硅砂 6 号 & 794 \\
\hline 混和材 & フライアッシュ & 596 \\
\hline 混和剤 & 減水剂 & 2.2 \\
\hline
\end{tabular}

表-2 低強度モルタルの配合（模擬地山）

\begin{tabular}{c|c|c}
\hline 材料 & 種類 & $\begin{array}{c}\text { 単位量 } \\
\left(\mathrm{kg} / \mathrm{m}^{3}\right)\end{array}$ \\
\hline 水 & & 649 \\
\hline セメント & 早強ポルトランドセメント & 185 \\
\hline 細骨材 & 硅砂 6 号 & 650 \\
\hline 混和材 & ベントナイト & 64.9 \\
\hline 混和剤 & 減水剂 & 17.1 \\
\hline 混和剤 & 分離防止剂 & 0.278 \\
\hline
\end{tabular}

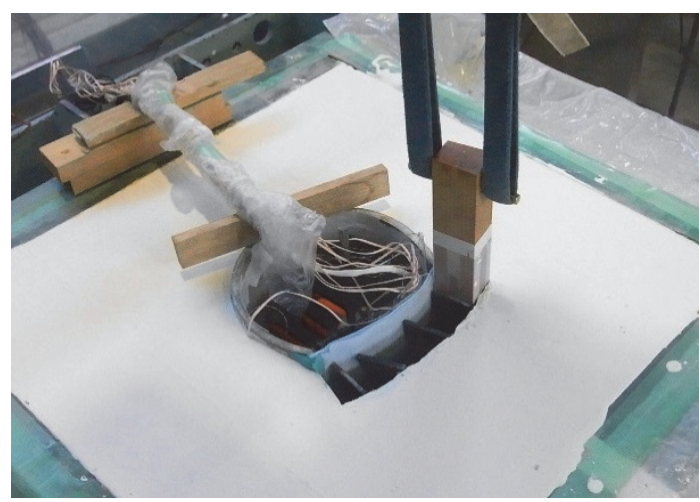

写真-1 スペーサー引き抜き状況

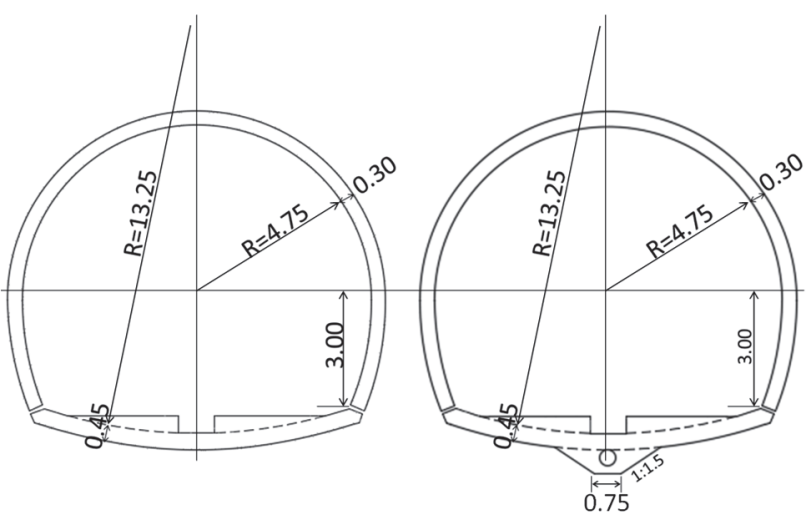

(a) $I_{\text {NiP }}$

(b) $\mathrm{I}_{\mathrm{NAiP}}$

図-6 実験ケース（単位 : m)

実験ケースは，図-6に示した 2 種類の新幹線複線断面 をもととし，それぞれの $1 / 50$ スケールで製作した模型の インバートの詳細な断面形状を図-7に示す。 


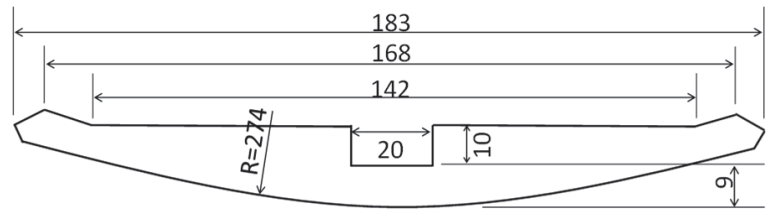

(a) $\mathrm{I}_{\mathrm{NiP}}$

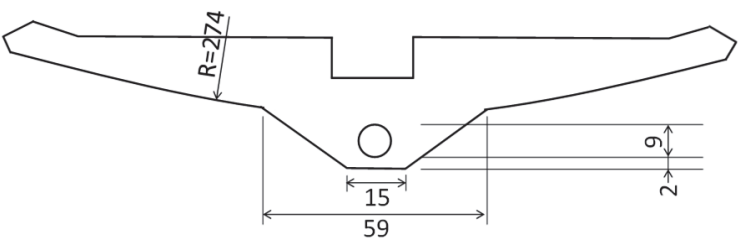

(b) INAiP

図-7 インバート模型の詳細図（単位 : mm）

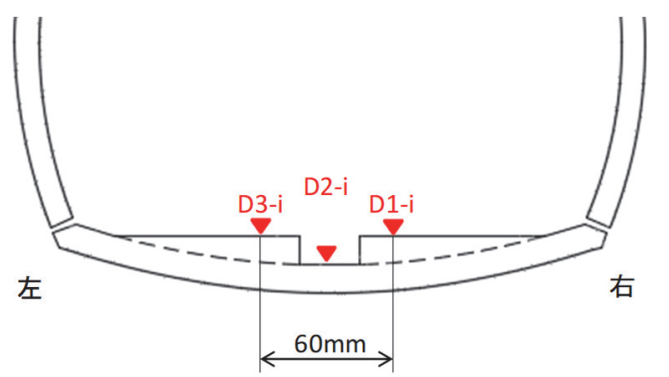

図-8 変位計設置位置

インバートの計測位置を図-8 に示寸． $\mathrm{I}_{\mathrm{NiP}}$ における計 測位置を示しているが， $\mathrm{I}_{\mathrm{NAiP}}$ も同様である. 図の位置に 変位計を設置し, 中央通路部とレール位置の隆起量の計 測を行った. トンネル軸方向の設置位置は中間部である. 計測は 5 分おきに行い，膨張モルタルの膨張が終わるま で実施した。

\section{(2) 実験結果}

実験は膨張モルタルの膨張が完了するまで実施した. 文献 21)では，変状が生じたトンネルの岩石を対象に多 くの吸水膨張圧試験を実施しており, 最大で $0.6 \mathrm{~N} / \mathrm{mm}^{2}$ 程度の吸水膨張圧が確認されている. 本実験と同じ配合 の膨張モルタルで測定した膨張圧と, 文献 21)で吸水膨 張圧が最も大きかった試料とで, 吸水膨張圧の経時変化 を図-9に示寸。これより，本実験で使用した膨張モルタ ルによって, 時間と共に進行する実際の岩石の膨張圧が 表現できており，実トンネル地山の大きい膨張圧の測定 データと同等の大きさの膨張圧が確認できていることが わかる。

写真-2 に $\mathrm{I}_{\mathrm{Nip}}$ の実験完了後の盤ぶくれの状況を，写真 -3 に $\mathrm{I}_{\mathrm{NAiP}}$ の状況を示寸．また，図-10に両ケースの膨張 モルタルの温度の変化を示寸. 膨張モルタルの膨張率は, 外部環境温度の影響を受けやすく, 膨張モルタルの温度 が高いほど, 膨張率も大きくなることが示されており 22),

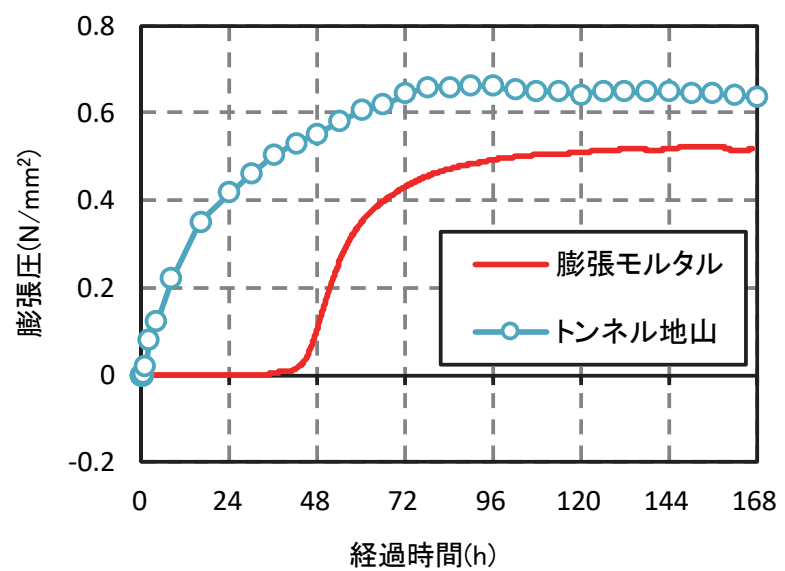

図-9＼cjkstart膨張モルタルの膨張圧

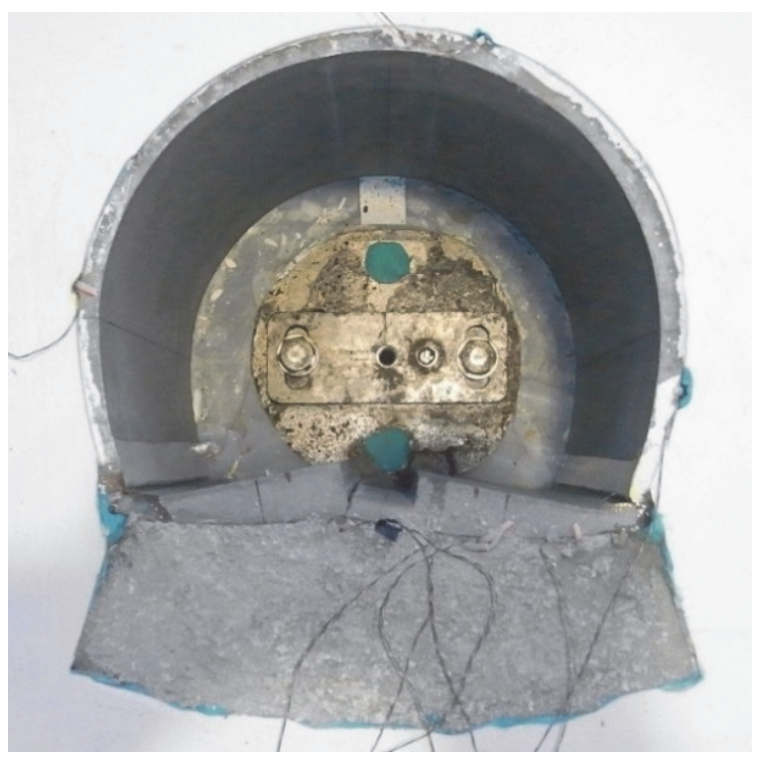

写真-2 盤ぶくれ状況（実験完了時 : $\mathrm{I}_{\mathrm{NiP}}$ ）

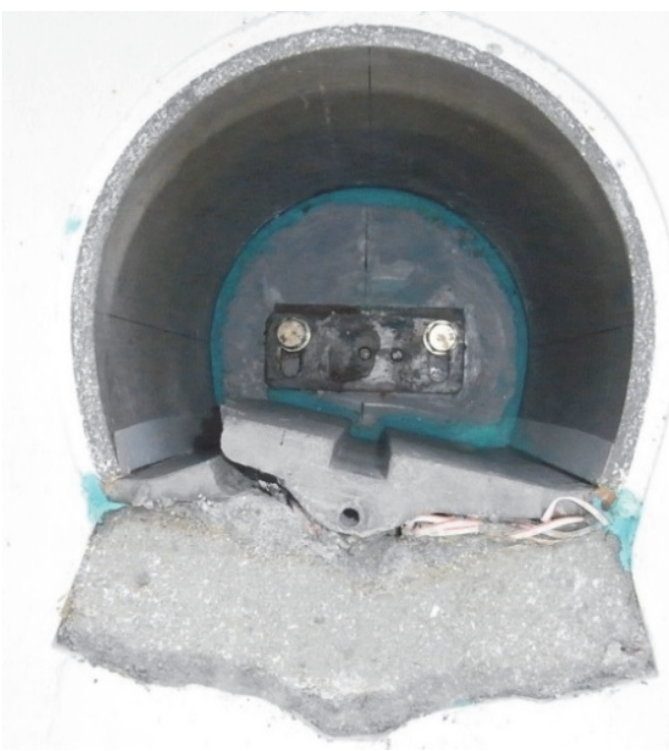

写真-3 盤ぶくれ状況（実験完了時 : INAiP) 


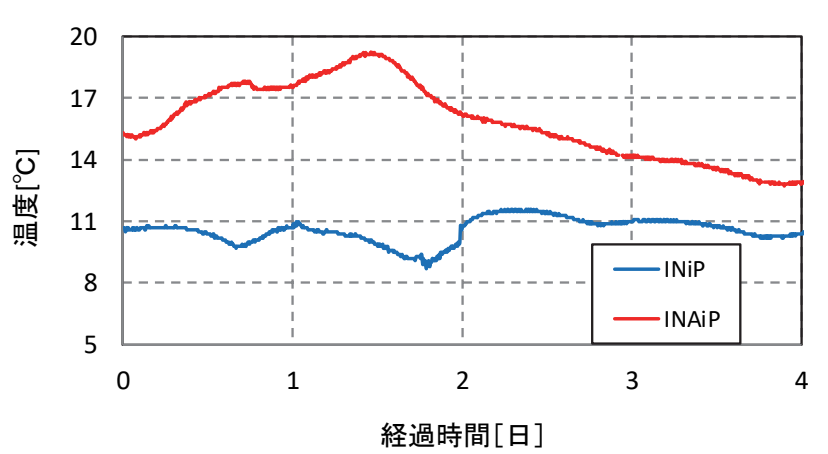

図-10＼cjkstart膨張モルタルの温度変化

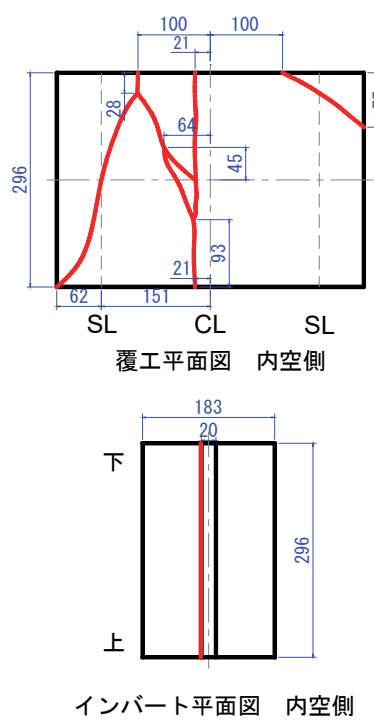

(a) INiP
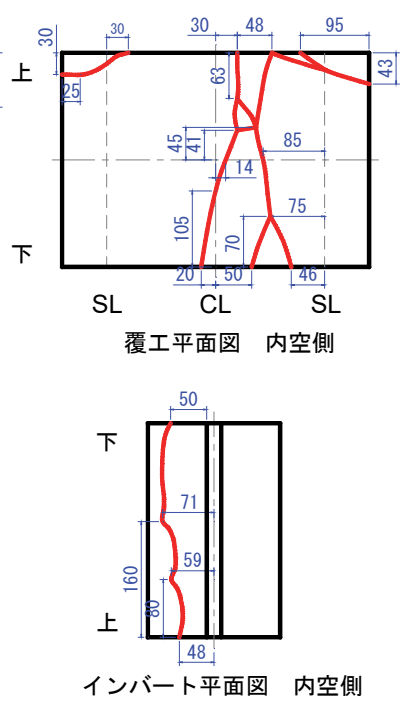

(b) INAiP
図-11 実験後のトンネル展開図（単位：mm）

本実験においては $\mathrm{I}_{\mathrm{NAiP}}$ の実験時の方が気温が高かったこ とから, 膨張モルタルの温度も高く, 膨張率も大きかっ たと考えている.

図-11 に実験後の覆工とインバートのひび割れを記入 した展開図を示寸.インバートにおいては， $\mathrm{I}_{\mathrm{NiP}}$ では，中 央通路の左下の隅角部からひび割れが入っている． $\mathrm{I}_{\mathrm{NAP}}$ では, 左側の軌道直下の位置からひび割れが入っている. それぞれ部材厚の小さいところや断面変化点が弱部とな り，ひび割れが発生した．鉄道トンネルにおいて，盤ぶ くれが発生した詳細な報告事例は少ないが，中央通路部 に縦断方向にひび割れが発生した事例 2) と, さらに横断 方向にもひび割れが発生した事例 ${ }^{11}$ が報告されている. 今回の実験では，横断方向のひび割れは発生しなかった が，実験模型では，インバートのトンネル軸方向の端部 が拘束されていないために横断方向の梁として曲げを受 けた結果, 縦断方向のみにひび割れが発生したと考えて おり，今回の実験では $\mathrm{I}_{\mathrm{NiP}}$ のインバートに発生したひび 割れの状況は，鉄道トンネルにおける実際の盤ぶくれ状 況を再現することができていると考えている. また, $\mathrm{I}_{\mathrm{NAiP}}$ の結果からは, 中央通路部にひび割れは発生しておらず

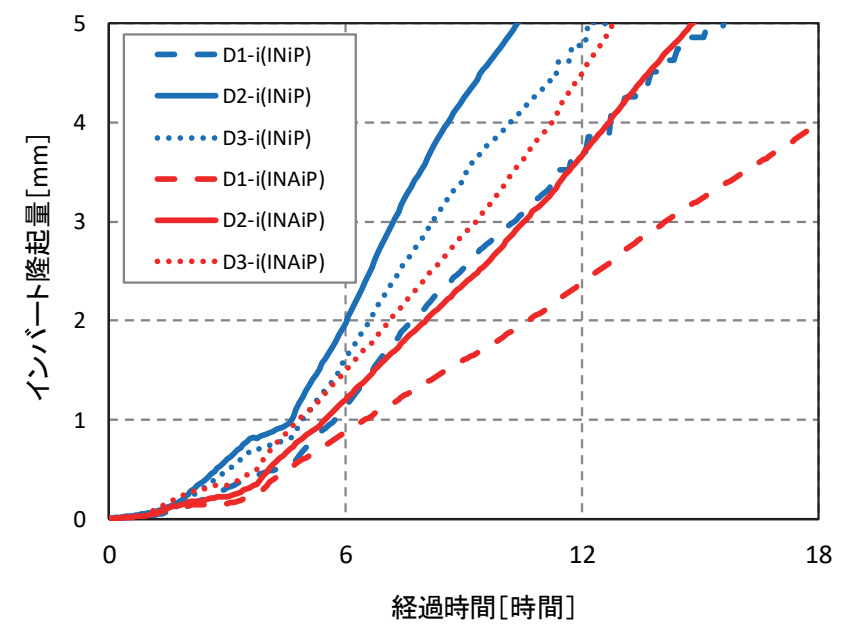

図-12 インバートの隆起量

鉄道トンネルのインバートの弱部を補強するという目的 を果たすことができる構造であることが確認できた。一 方で，覆工には概ねトンネル軸方向にひび割れが入って おり，インバート構造の違いによる終局時点での破壊形 態については，明瞭な差は見て取れない。

図-12 に盤ぶくれ開始からの経過時間と隆起量の関係 を示寸. 盤ぶくれ開始当初において, $\mathrm{I}_{\mathrm{NiP}}$ では左右のレー ル位置（D1-i および D3-i）よりも中央通路部（D2-i）の 隆起量が大きく， I IAiP では D3-i，D2-i，D1-i の順になっ ていることから，左側が持ち上がり，左側がより大きく 隆起寸る変形形態になっていたことが分かる. 実験ケー スごとで比較すると, 同じ計測位置では中央通路部, レ 一ル位置ともに $\mathrm{I}_{\mathrm{NAiP}}$ の方が盤ぶくれを抑制することがで きている. 図に示すように隆起量が $2 \mathrm{~mm}$ に到達する最 も早い計測位置での所要時間で比較すると, $\mathrm{I}_{\mathrm{NAiP}}$ の方が $16 \%$ 長く, 3 箇所の平均では $26 \%$ 長くなっている. また, $\mathrm{I}_{\mathrm{NiP}}$ で隆起量が最初に $2 \mathrm{~mm}$ に到達する, 経過時間 6 時間 における隆起量で比較すると, 平均で $23 \%$ 抑制すること ができている.

ただし, 文献 22)に示すように, 膨張モルタルの膨張 圧は一様ではなく, 両ケースを厳密に比較するためには, 温度によって変わる膨張モルタルの膨張圧を厳格にコン トロールした実験が必要であるが，それは現実的には困 難である. そのため本論文では，同条件，対象での定量 的な評価を行うため, 次章において数值解析を実施して いる.

なお，実験は 1/50 のスケールで実施しているため, $2 \mathrm{~mm}$ の隆起量は実際には $100 \mathrm{~mm}$ に相当する. 実験は静 的破砕剂によって盤ぶくれを再現しているため, 静的破 砕剤の反応が終わるまて盤ぶくれが継続している.また, 隆起量に関する軌道整備基準では，例えば JR 東日本 ${ }^{23}$ ) の場合, 列車速度が時速 $245 \mathrm{~km}$ 以上の区間では $12 \mathrm{~mm}$ と なっており，現実には盤ぶくれが $100 \mathrm{~mm}$ となる前に口 
ックボルト打設などの対策工を実施するものと思われる 軌道整備基準は $10 \mathrm{~m}$ 弦での変位量を基準としているた めに，一概には比較できないものの，実験結果を評価す る範囲としては妥当であると考えており，定性的に見て も， $\mathrm{I}_{\mathrm{NAiP}}$ は盤ぶくれに対して $\mathrm{I}_{\mathrm{NiP}}$ と同等以上の抑制効果 があると考える.

\section{4. 模型実験の再現解析}

\section{(1) 解析の概要}

模型実験ではインバートが隆起し，破壊に至る過程を 盤ぶくれの状況や計測結果から確認することができたも のの，膨張モルタルは周囲の気温によって膨張圧が異な ることから，条件を同一とするために，数值解析による 再現解析を行うこととした．解析は二次元平面ひずみ状 態とし，有限差分法 $\left(\right.$ FLAC $\left.^{3 \mathrm{D}}\right)$ により行った.

解析モデル図を図-13 に示す。寸法は模型実験と同様 としており，対称性を考慮して半断面をモデル化してい る.インバートを含む覆工模型と地山モルタル，膨張モ ルタルとの間は，滑りと分離を表現できるインターフェ イス要素 24)を配置している.

解析では，膨張モルタルの要素の $\sigma_{\mathrm{xx}}, \sigma_{\mathrm{yy}} ， \sigma_{\mathrm{zz}}$ につい て， 1 ステップあたり $0.02 \mathrm{~N} / \mathrm{mm}^{2}$ 増加させるステップを 100 ステップ繰り返した。 すなわち，最終ステップでの 膨張圧は $2.0 \mathrm{~N} / \mathrm{mm}^{2}$ となる.ただし,この膨張圧 $2.0 \mathrm{~N} / \mathrm{mm}^{2}$ は，膨張モルタルが完全に変位が拘束された状態であれ ば $2.0 \mathrm{~N} / \mathrm{mm}^{2}$ の膨張圧になるということであるが，周辺 の地山モルタルやインバートが変形するため, 膨張圧が 減少し，インバートに作用する応力としては $2.0 \mathrm{~N} / \mathrm{mm}^{2}$ より小さい值となる.

覆工模型のコンクリートの入力物性值を表-3 に示す. コンクリートはひずみ軟化モデルとしており，ひび割れ を表現することを目的として，式(1)に示すようにひび割 れ発生時の応力を $\sigma_{c r}$, ひび割れ発生時のひずみを $\varepsilon_{c r}$, 引 張軟化係数を $\alpha$ として，引張破壊後に発生する引張ひず みの増加に伴って, 引張強さ $\sigma_{t}$ を指数関数で低下させて いる ${ }^{25), 26) . ~}$

$$
\sigma_{t}=\sigma_{c r} \cdot \exp \left(-\alpha \cdot\left(\varepsilon-\varepsilon_{c r}\right)\right)
$$

また，ひずみの増加に伴って低下するせん断強さ $c$ を 式(2)に示すように，軟化開始時のせん断強さを $c_{c r}$ ，せん 断ひずみを $\varepsilon_{c r}^{\prime}$ ，軟化係数を $\beta$ として表している.

$$
c=c_{c r} \cdot \exp \left(-\beta \cdot\left(\varepsilon^{\prime}-\varepsilon^{\prime}{ }_{c r}\right)\right)
$$

地山モルタルの入力物性值は，過去に実施した同配合 のモルタルの強度試験結果等を参考に，表-4のように設 定した．地山モルタルは Mohr-Coulomb の破壊規準に従 う弾塑性モデル，膨張モルタルは弾性モデルとした。

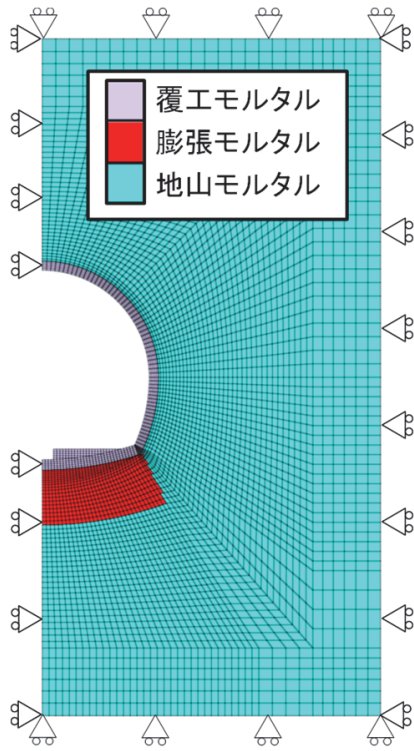

図-13 解析モデル $\left(\mathrm{I}_{\mathrm{NiP}}\right)$

表-3 解析入力物性值 (覆工模型)

\begin{tabular}{c|c|c}
\hline \multicolumn{2}{c|}{ 項目 } & 物性值 \\
\hline 一軸圧縮強さ & $q_{u}$ & $24 \mathrm{~N} / \mathrm{mm}^{2}$ \\
\hline 弾性係数 & $E$ & $22000 \mathrm{~N} / \mathrm{mm}^{2}$ \\
\hline ポアソン比 & $v$ & 0.2 \\
\hline せん断強さ & $c$ & $5.6 \mathrm{~N} / \mathrm{mm}^{2}$ \\
\hline 内部摩擦角 & $\phi$ & $40^{\circ}$ \\
\hline ダイレイタンシー角 & $\psi$ & $12^{\circ}$ \\
\hline 引張強さ & $\sigma_{t}$ & $1.91 \mathrm{~N} / \mathrm{mm}^{2}$ \\
\hline
\end{tabular}

表-4 解析入力物性值（地山モルタル）

\begin{tabular}{c|c|c}
\hline \multicolumn{2}{c|}{ 項目 } & \multicolumn{1}{c}{ 物性值 } \\
\hline 弾性係数 & $E$ & $80 \mathrm{~N} / \mathrm{mm}^{2}$ \\
\hline ポアソン比 & $v$ & 0.3 \\
\hline 粘着力 & $c$ & $0.15 \mathrm{~N} / \mathrm{mm}^{2}$ \\
\hline 内部摩擦角 & $\phi$ & $13^{\circ}$ \\
\hline
\end{tabular}

\section{(2) 解析結果}

最大主ひずみ（引張ひずみ）コンター図を，図-14 に 示す． $\mathrm{I}_{\mathrm{NiP}}$ では中央通路隅角部に， $\mathrm{I}_{\mathrm{NAiP}}$ では中央通路と側 壁脚部の中間位置で引張ひずみが大きくなっており，実 験の結果を再現できていることがわかる．引張ひずみの

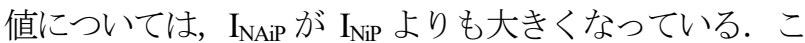
れはひび割れ発生箇所の巻き厚が $\mathrm{I}_{\mathrm{NAiP}}$ の方が厚いため, ある変化量に対するひび割れ幅は大きくなったと考えら れる。

次に，インバートの隆起量について示す.ここでの隆 起量は，実験と同様に覆工の天端との相対変位で表し， インバート中央の位置 (以下, CL という) について図-15 に示す．横軸には膨張モルタルの要素に与えた膨張圧を 
示している.この膨張圧が $1.0 \mathrm{~N} / \mathrm{mm}^{2}$ の時点で比較する と, $\mathrm{I}_{\mathrm{NAiP}}$ のインバート隆起量は $\mathrm{I}_{\mathrm{NiP}}$ の $55 \%$ 程度に抑えら れているのが分かる. また, $\mathrm{I}_{\mathrm{NiP}}$ は膨張圧 $1.05 \mathrm{~N} / \mathrm{mm}^{2}$ 時に ひび割れが急激に進行し, 隆起量が急増しているが, $\mathrm{I}_{\mathrm{NAiP}}$ では膨張圧の増加に対して線形的に隆起量の増加が続い ている. $\mathrm{I}_{\mathrm{NAiP}}$ は $\mathrm{I}_{\mathrm{NiP}}$ に比べて施工性を大きく損なわない ことを重視して，中央集水管設置のために掘削する範囲 をやや拡大し，従来は砕石で埋め戻していた範囲を含め てコンクリートでインバートと一体化させた。 それによ つて, 中央通路部の剛性は高くなったものの, その効果, 特に $\mathrm{I}_{\mathrm{NiP}}$ と比べて明瞭な差があるかは明らかではなかっ たが，模型実験ならびに本章の数值解析によって，イン バート下の地山が膨張し，インバートが盤ぶくれするよ うな地山において， $\mathrm{I}_{\mathrm{NAiP}}$ は従来の $\mathrm{I}_{\mathrm{NiP}}$ に比べて盤ぶくれ を抑制する効果を有していると言える.

\section{5. 実トンネルを想定した解析による盤ぶくれ抑 制効果の評価}

\section{(1) 解析の概要}

模型実験および前章における解析のような，トンネル 全体の構造を模擬した再現解析では，インバートの隆起

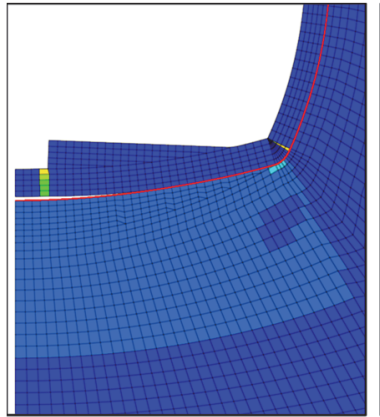

(a) $\mathrm{I}_{\mathrm{NiP}}$

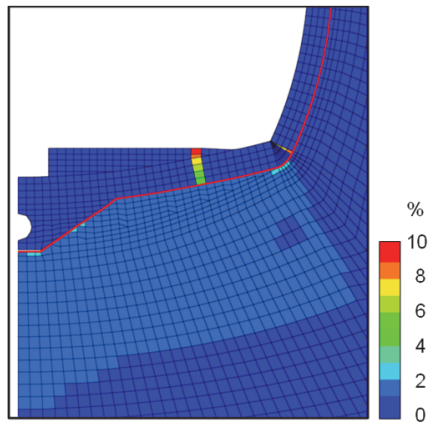

(b) $\mathrm{I}_{\mathrm{NAiP}}$ 図-14＼cjkstart最大ひずみコンター図（変形倍率 5 倍）

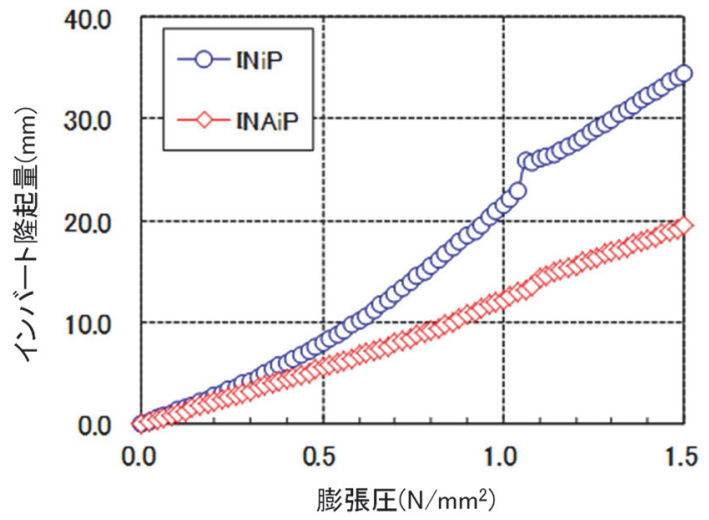

図-15 インバートの隆起量 (CL)
土木学会論文集F1 (トンネル工学), Vol. 75, No. 1, 116-129, 2019.

の状況，計測結果および解析結果から $\mathrm{I}_{\mathrm{NAiP}}$ の中央通路部 の補強効果や盤ぶくれ抑制効果を確認することができた. ただし，盤ぶくれ抑制効果について，これまで多く採用 されてきたインバート形状との相対的な比較を行うため, 別途，解析による検証を行う。解析ケースは実験を行っ た $\mathrm{I}_{\mathrm{NiP}}$ と $\mathrm{I}_{\mathrm{NAiP}}$ に加えて，比較のために $\mathrm{I}_{\mathrm{S}}$ 地山で適用され る $\mathrm{I}_{\mathrm{SiP}}$ も対象とした. Is 地山は, 著しい膨圧の発生はない ものの，掘削時の内空変位の収束に，吹付コンクリート による一次インバートを要するような地山である ${ }^{12)}$. 具 体的には，新第三紀から第四紀更新世の堆積岩類または 堆積物や変質およひ破砕の進行した岩石等で，地山強度 比が概ね 2 以下である地山を指す。そのため，標準的な インバート形状のなかでは，半径が最も小さい.

解析モデルは前章と同様に，地山と覆工，インバート をモデル化した．解析ケースごとのインバートの形状を 図-16 に示す。法は新幹線複線断面の実物大である.

インバートの盤ぶくれやその対策工の効果の検証を 目的としたこれまでの研究では，第 4 章のように地山と 覆工，インバートを対象としてモデル化を行っている事 例が多い 8),27)。このような解析は，より精度の高い結果 を得るためには有効な手法であるが，本研究で目標とし ている実際の施工現場への適用を考慮した場合，解析に

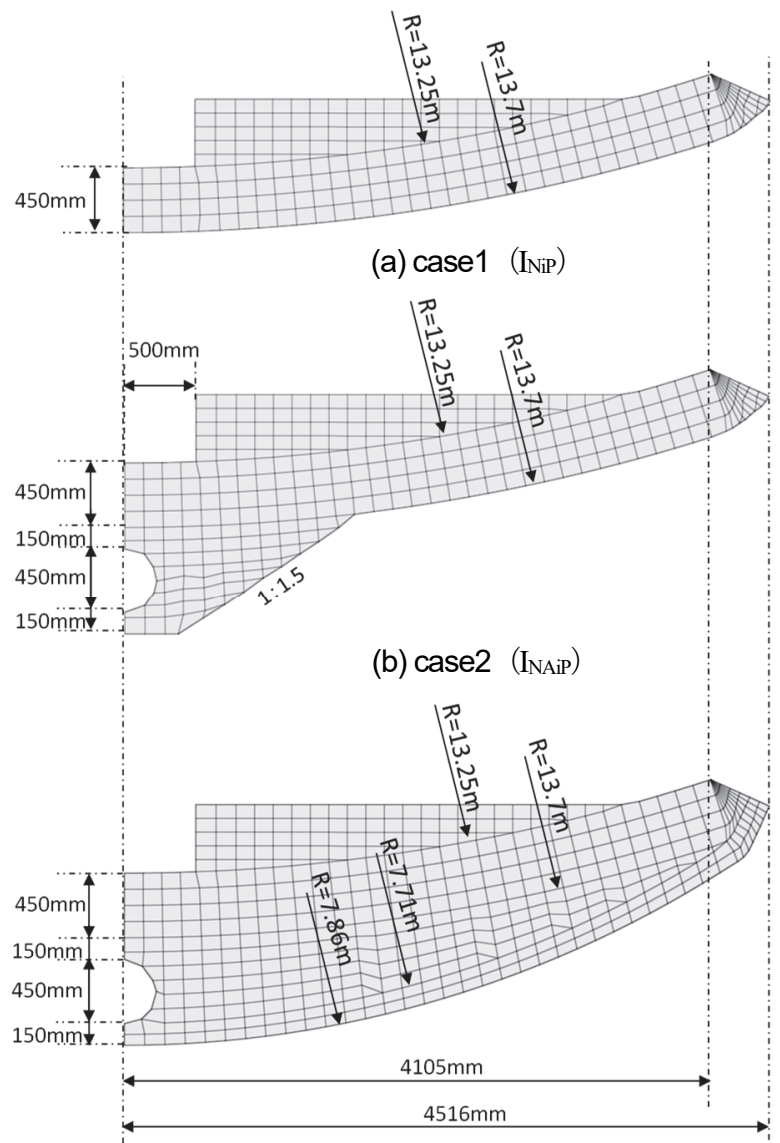

(c) case3 (Isip)

図-16 解析モデル 
表-5 解析パターン

\begin{tabular}{c|c|c}
\hline 解析パターン & モデル化の対象 & 境界条件 \\
\hline パターン 1 & インバート & 端部鉛直固定, 水平自由 \\
\hline パターン 2 & インバート & 端部鉿直固定, 水平固定 \\
\hline パターン 3 & $\begin{array}{c}\text { インバート, } \\
\text { 覆工, 地山 }\end{array}$ & 地山の境界を完全固定 \\
& \\
\hline
\end{tabular}

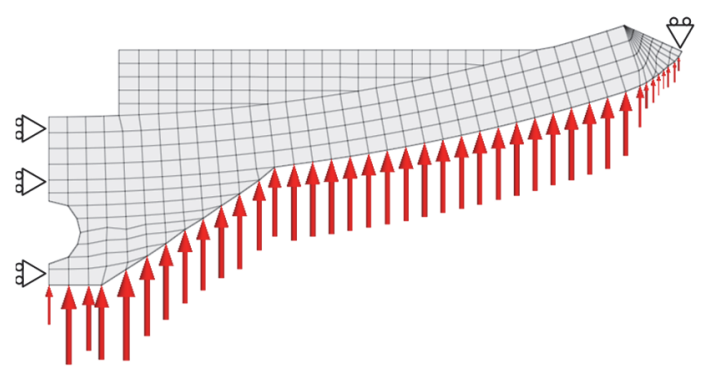

(a) パターン 1

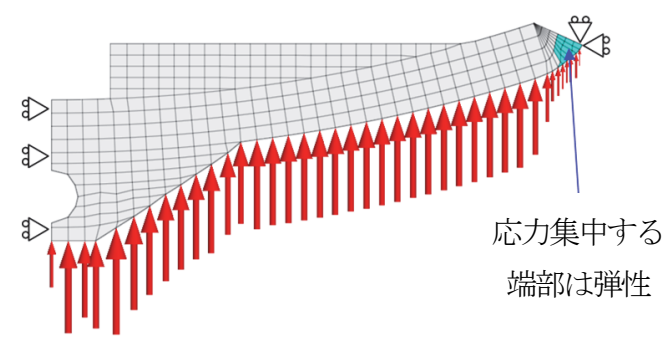

(b) パターン 2

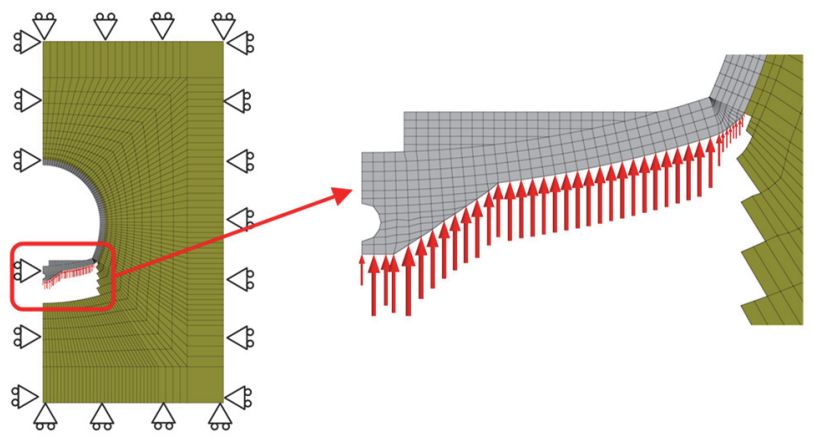

(c) パターン 3

図-17 境界条件（ $\mathrm{I}_{\text {NAiP }}$ の例）

時間を要することはデメリットとなる，そのため本章で は，解析の簡略化を図るため，インバート部のみをモデ ル化したケースも準備した. しかし，インバート部のみ を対象とした解析モデルを使用し，解析結果を実際の盤 ぶくれの挙動と比較することでインバートと覆工の境界 条件について評価した研究が無いことから，モデル化の 対象範囲や境界条件を表-5 および図-17 のように変えた 3 パターンを設定した. 荷重はインバートの下面に等分 布荷重を鉛直上向きに作用させ，盤ぶくれを再現する荷 重漸増解析を行った. 本解析条件は, 前章のように要素 に膨張圧を与えるのではなく, 荷重制御で荷重を漸増さ せる解析であり，コンクリートは非線形モデルとしてい
表-6 解析入力物性值 (コンクリート)

\begin{tabular}{c|c|c}
\hline \multicolumn{2}{c|}{ 項目 } & 物性值 \\
\hline 一軸圧縮強さ & $q_{u}$ & $21 \mathrm{~N} / \mathrm{mm}^{2}$ \\
\hline 弾性係数 & $E$ & $20000 \mathrm{~N} / \mathrm{mm}^{2}$ \\
\hline ポアソン比 & $v$ & 0.2 \\
\hline せん断強さ & $c$ & $4.9 \mathrm{~N} / \mathrm{mm}^{2}$ \\
\hline 内部摩擦角 & $\phi$ & $40^{\circ}$ \\
\hline ダイレイタンシー角 & $\psi$ & $12^{\circ}$ \\
\hline 引張強さ & $\sigma_{c t}$ & $1.75 \mathrm{~N} / \mathrm{mm}^{2}$ \\
\hline
\end{tabular}

表-7 解析入力物性值（地山）

\begin{tabular}{c|c|c}
\hline \multicolumn{2}{c|}{ 項目 } & 物性值 \\
\hline 弾性係数 & $E$ & $206 \mathrm{~N} / \mathrm{mm}^{2}$ \\
\hline ポアソン比 & $v$ & 0.36 \\
\hline 粘着力 & $c$ & $0.58 \mathrm{~N} / \mathrm{mm}^{2}$ \\
\hline 内部摩擦角 & $\phi$ & $31^{\circ}$ \\
\hline ダイレイタンシー角 & $\psi$ & $10^{\circ}$ \\
\hline 側圧係数 & $K$ & 1.0 \\
\hline
\end{tabular}

るため, 荷重増加とともに非線形的に隆起が進行する.

次に, 覆工, インバートの物性值を表-6 に示す. コン クリートは Mohr-Coulomb の破壊規準に従う弾塑性モデ ルとし，ひび割れを表現することを目的として，前章と 同様に引張強さを式(1)で低下させている.

地山の物性值を表-7 に示す. 地山は地山等級 Is を想定 し, 一軸圧縮強さは, 地山強度比を 0.5 , 単位体積重量 $20.0 \mathrm{kN} / \mathrm{m}^{3}$ ，土被り $200 \mathrm{~m}$ とした場合に求められる $2.0 \mathrm{~N} / \mathrm{mm}^{2}$ としているの.これらは過去の研究において実 施した数值解析において, 掘削時の内空変位量が $100 \mathrm{~mm}$ 程度となることが分かっている．山岳トンネル設計施工 標準・同解説 ${ }^{12)}$ では内空変位量による地山等級の区分が 示されており，100mm〜 $150 \mathrm{~mm}$ では $\mathrm{Is}_{\mathrm{S}}$ と区分されるこ とから， $\mathrm{I}_{\mathrm{NAiP}}$ の適用を想定している， $\mathrm{I}_{\mathrm{N}}$ と $\mathrm{I}_{\mathrm{S}}$ の境界付近 の地山と一致する. その他の物性值については, アイダ ンら ${ }^{28)}$, 赤木ら ${ }^{29)}$, 蒋ら ${ }^{30)}$ が示した軟岩の一軸圧縮強さ と各種物性值の相関関係より設定している.

\section{(2) 解析結果}

a) パターン 1

パターン 1 の解析結果として, 横軸にインバートへの 載荷圧, 縦軸にインバート中央部の隆起量としたグラフ を図-18 に示す. $\mathrm{I}_{\mathrm{NiP}}$ で $0.14 \mathrm{~N} / \mathrm{mm}^{2}, \mathrm{I}_{\mathrm{NAiP}}$ で $0.36 \mathrm{~N} / \mathrm{mm}^{2}$, $\mathrm{I}_{\mathrm{SiP}}$ では $0.73 \mathrm{~N} / \mathrm{mm}^{2}$ の載荷圧で隆起量はいずれも $5 \mathrm{~mm}$ 程 度で変位が急激に増加し, 発散する結果となった. 発散 する直前のステップにおける引張ひずタコンター図を図 -19 に示す. 変形倍率は図に各々表記されているとおり であり, 水色は変形前の形状を表している． $I_{\mathrm{NiP}}, \mathrm{I}_{\mathrm{Sip}}$ で 


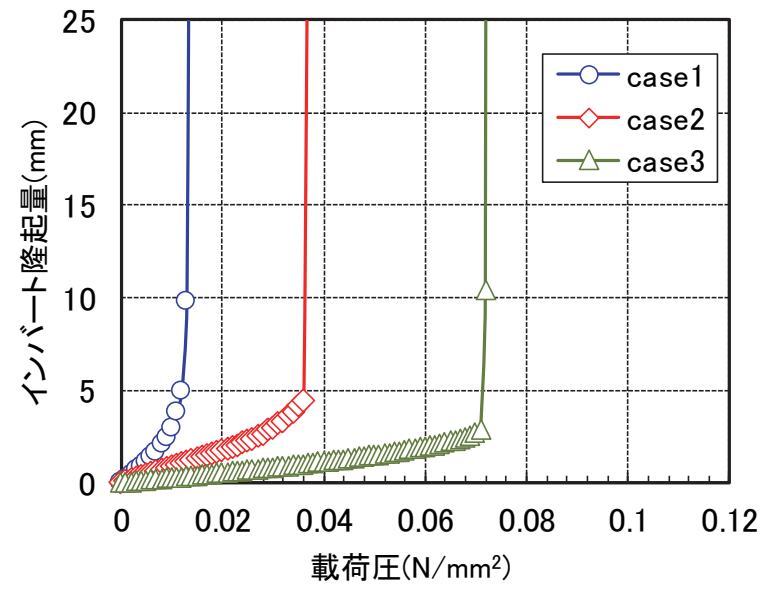

図-18 載荷圧とインバート隆起量（パターン 1)

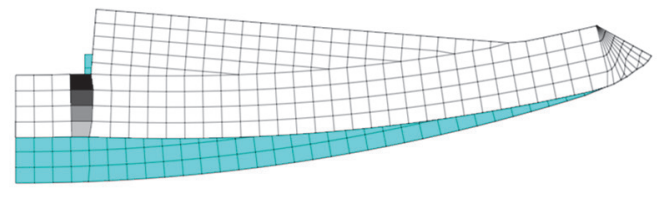

発散する直前 (変形倍率等倍)

(a) case1

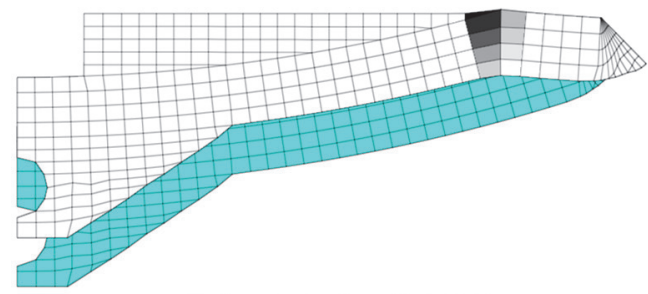

発散する直前 (变形倍率等倍)

(b) case2

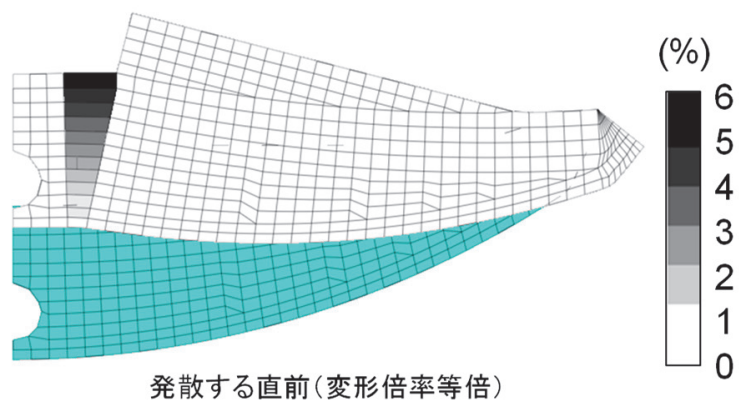

(c) case3

図-19 引張ひずみコンター図（パターン1）

は中央通路隅角部で， $\mathrm{I}_{\mathrm{NAiP}}$ ではインバート天端の水平部 と内面曲線の摺り付き部でひび割れが発生していること がわかる． $\mathrm{I}_{\mathrm{NiP}}, \mathrm{I}_{\mathrm{NAiP}}$ のひび割れ発生位置が実験や実現象 に似ているものの, 隆起量 $5 \mathrm{~mm}$ で解析が発散しており, 盤ぶくれの予測や対応策の検討などの実務上の解析方法 としては，境界条件の設定が適切ではないと思われる.
土木学会論文集F1 (トンネル工学), Vol. 75, No. 1, 116-129, 2019.

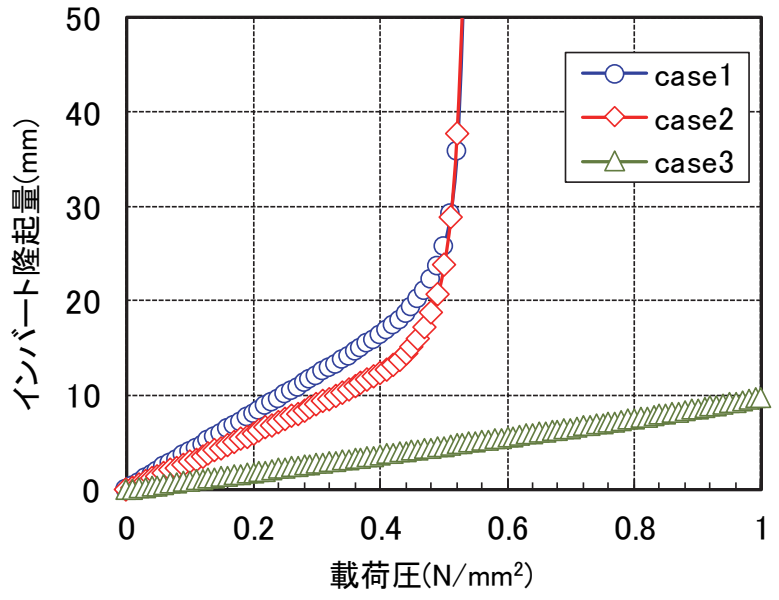

図-20＼cjkstart載荷圧とインバート隆起量（パターン2）

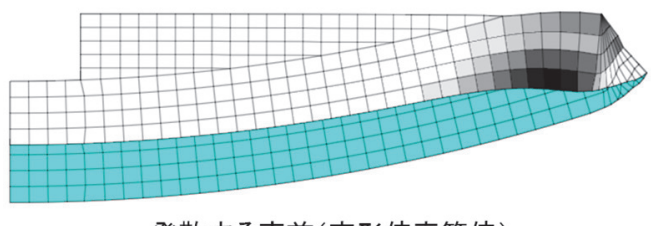

(a) case1

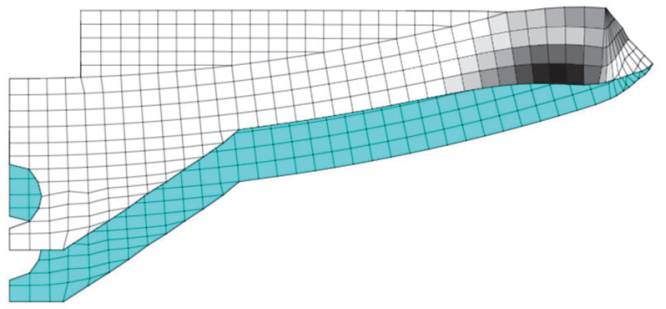

発散する直前 (変形倍率等倍)

(b) case2

(\%)

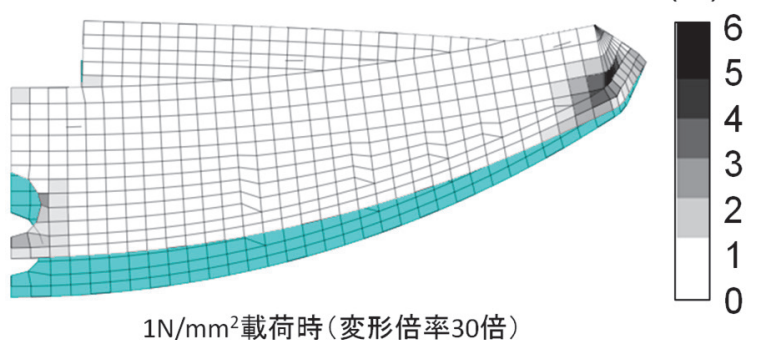

(c) case3

図-21 引張ひずタコンター図（パターン2）

b) パターン 2

パターン 2 の解析結果を図-20 に示寸. I I を載荷した時点でも弾性的な挙動を示したが， $\mathrm{I}_{\mathrm{NPP}} ， \mathrm{I}_{\mathrm{NAiP}}$ では $0.5 \mathrm{~N} / \mathrm{mm}^{2}$ 程度で大きな変位が発生し, 発散した. $\mathrm{I}_{\mathrm{NiP}}$ と $\mathrm{I}_{\text {NAiP }}$ の結果を比較すると， $\mathrm{I}_{\mathrm{NAiP}}$ の方が変形は小さかっ たものの，その差は僅少であった，発散する直前のステ ップ（ $\mathrm{I}_{\mathrm{Sip}}$ は $1 \mathrm{~N} / \mathrm{mm}^{2}$ 載荷時）における引張ひずみコンタ 一図を図-21に示寸，いずれの形状においても，破壊 


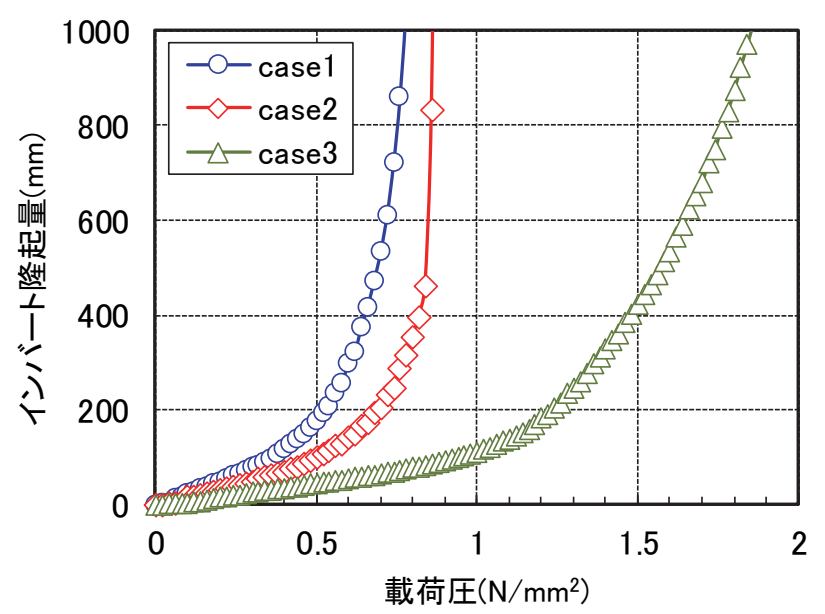

図-22 載荷圧とインバート隆起量（パターン3)

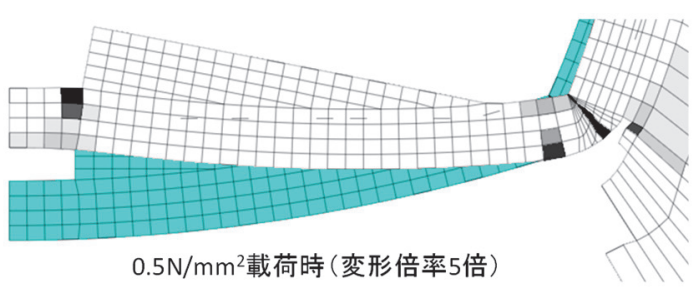

(a) case 1

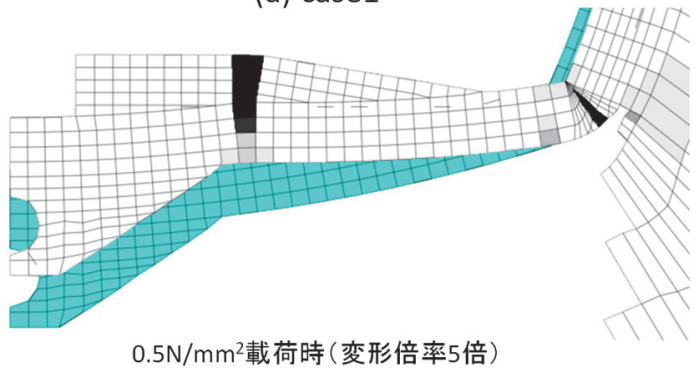

(b) case2

$(\%)$

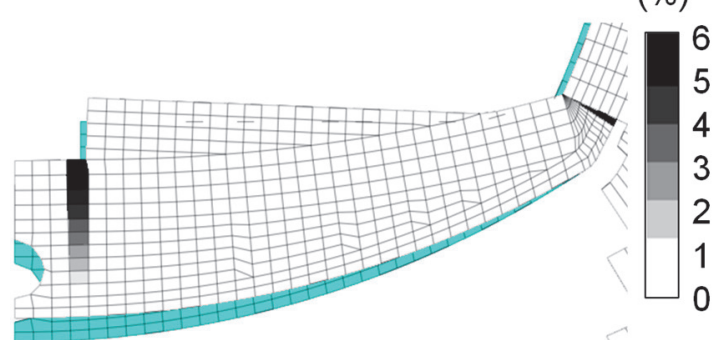

$0.5 \mathrm{~N} / \mathrm{mm}^{2}$ 載荷時 (変形倍率5倍)

(c) case3

図-23 引張ひずみコンター図（パターン3）

がインバートの側壁側で発生しており， $\mathrm{I}_{\mathrm{NAiP}}$ のような中 央通路部の増し厚が効果を発揮しない変形モードとなっ ていることがわかる．また $\mathrm{I}_{\mathrm{NiP}}$ では，実際の被害事例や 実験結果とは異なった破壊形態であり，境界条件の設定 がパターン 1 と同様, 適切ではないと思われる.

c) パターン 3

パターン 3 の解析結果を図-22 に示す。 I I SiP では載荷圧 $1.2 \mathrm{~N} / \mathrm{mm}^{2}$ あたりから載荷圧の増加に対して非線形的に
土木学会論文集F1 (トンネル工学), Vol. 75, No. 1, 116-129, 2019.

インバート隆起量が増加しているが, $2.0 \mathrm{~N} / \mathrm{mm}^{2}$ を載荷し た時点でも発散はしなかった. $0.5 \mathrm{~N} / \mathrm{mm}^{2}$ 載荷時における 引張ひずみコンター図を図-23 に示す，また，この時点 におけるインバート中央部の隆起量についても併記して いる. $\mathrm{I}_{\mathrm{NiP}}, \mathrm{I}_{\mathrm{SiP}}$ はパターン 2 と同じく中央通路隅角部で ひび割れが発生しており， $\mathrm{I}_{\mathrm{NAiP}}$ は中央集水管巻き立ての 摺り付き部の内面側でひび割れが発生している. $\mathrm{I}_{\mathrm{NiP}}$, $\mathrm{I}_{\mathrm{NAiP}}$ のひび割れ位置は，実験の結果と同様である $0.5 \mathrm{~N} / \mathrm{mm}^{2}$ 載荷時の隆起量は $\mathrm{I}_{\mathrm{NiP}}, \mathrm{I}_{\mathrm{NAiP}}, \mathrm{I}_{\mathrm{SiP}}$ の順に大きく なっている. なお, パターン 3 はパターン 1 と比較する と 20 倍以上の大きな載荷圧に対しても, 大きな変位が生 じるものの解析は発散せずに形状を保っている.

また $\mathrm{I}_{\mathrm{NiP}}$ と $\mathrm{I}_{\mathrm{NAiP}}$ の結果からは， $\mathrm{I}_{\mathrm{NAiP}}$ の方が変形は小さ < 460mm 隆起したステップの次から急激に隆起が進行 しており，これが解析上の限界隆起量と捉えても，実務 上の解析手法としては十分であると考えられ，境界条件 の設定方法などが妥当であったと考えている．この時の 盤ぶくれ抑制効果は, $0.5 \mathrm{~N} / \mathrm{mm}^{2}$ 載荷時の変位量で比較寸 ると， $\mathrm{I}_{\mathrm{NiP}}$ の隆起量に対して $\mathrm{I}_{\mathrm{NAiP}}$ では $56 \%$ ， $\mathrm{I}_{\mathrm{SiP}}$ では $25 \%$ となっており， $\mathrm{I}_{\mathrm{NAiP}}$ の盤ぶくれ抑制効果を示すとともに, $\mathrm{I}_{\mathrm{NiP}}$ と $\mathrm{I}_{\mathrm{SiP}}$ の中間的な役割を果たしていることが分かった。 本章では，インバートの盤ぶくれを再現する解析の簡 略化のためにモデルの単純化を検討したが，覆工とイン バートの接合部の境界条件の設定は単純化できず，実際 のインバートに近い挙動を表現するためには, 地山とト ンネルをモデル化する必要があることが分かった. また, これらのことから，インバートの盤ぶくれに対寸る耐力 は側壁脚部との軸力伝達や覆工背面の地盤反力にも大き な影響を受けるものと考えられる。

\section{6. まとめ}

本研究では, 整備新幹線の山岳トンネルにおける新し いインバート構造（ $\mathrm{I}_{\text {NAiP }}$ ）について模型実験および数值 解析を行った. $\mathrm{I}_{\mathrm{NAiP}}$ は施工性を損なわないことを重視し て検討し, 定められた構造であったために, 盤ぶくれに 対する効果については明らかではなかったが，本研究に より次のような結果が得られた。

（1）模型実験後の破壊形態より， I IAiP は一般的なイン バートの弱部である中央通路部にひび割れは発 生せず，中央通路部が補強されていることが確認 できた.

（2） 再現解析では, 実験におけるインバートの破壊形 態と同様な結果が得られ，その解析結果から，中 央通路部の隆起量で， $\mathrm{I}_{\mathrm{NAiP}}$ は従来の $\mathrm{I}_{\mathrm{NiP}}$ に比べ, 約 55\%程度に盤ぶくれを抑制する効果を有して いることが分かった。 
（3）標準的なインバート形状との相対的な比較を行 うため， ISiP も加えた解析を実施し，同じく中央 通路部の隆起量で $\mathrm{I}_{\mathrm{NiP}}$ に対して $\mathrm{I}_{\mathrm{NAiP}}$ では $56 \%$, $\mathrm{I}_{\mathrm{SiP}}$ では 25\%と $\mathrm{I}_{\text {NAiP }}$ は $\mathrm{I}_{\mathrm{NiP}}$ と $\mathrm{I}_{\mathrm{Sip}}$ との中間的な盤ぶく れ抑制効果が期待できることが分かった.

（4）解析では, 解析の簡略化を図るため, モデル化の 対象範囲や境界条件を変えた解析も併せて実施 した. 変形モードおよび隆起量の解析結果からは, 側壁とインバートの接合部の境界条件の設定は 単純化できず, 実際のインバートに近い挙動を表 現するためには, 地山とトンネルをモデル化する 必要があることが分かった。

今回検討の対象とした $\mathrm{I}_{\mathrm{NAiP}}$ は, これまで一般的な地山 で採用されてきた $\mathrm{I}_{\mathrm{NiP}}$ とインバートの掘削半径は同じで あり，中央集水管部分を幅広く掘削するのみで施工性や 経済性は $\mathrm{I}_{\mathrm{NiP}}$ と同程度であると考えている。一方で，こ のように部分的に中央通路部を補強することで，効果的 に盤ぶくれ抑制効果を向上させることが分かった.

過去の経験から将来の盤ぶくれを㲘念する地山で $\mathrm{I}_{\mathrm{NAiP}}$ の適用を進めることで，その施工性や経済性を活用した 盤ぶくれ抑止対策として，山岳トンネル施工ならびにト ンネルの長期的な安定性の確保や維持管理の低減に寄与 できるものと考えている.

$\mathrm{I}_{\mathrm{NAiP}}$ の導入により, 完成後の盤ぶくれの発生の恐れが 減少しているものと考えられるが，現状では，インバー 卜設計施工フローを適用し， $\mathrm{I}_{\mathrm{NAiP}}$ を施工したトンネルの 事例が少なく，長期にわたる観察や計測データの蓄積が まだできていない，今後は，フローの判定基準や，想定 された地山に対して $\mathrm{I}_{\mathrm{NAiP}}$ が十分な盤ぶくれ抑制効果を発 揮するか，施工事例を蓄積していきながら，検証してい く必要がある. そのため, 今回示した模型実験や数值解 析の他に，施工事例の分析により， $\mathrm{I}_{\mathrm{NAiP}}$ の盤ぶくれ抑制 効果の検証や評価の実施も行う予定である.

\section{参考文献}

1) 斉藤道真，秋田勝次，蓼沼慶正，丸山修，上野光，渡 辺和之: 山岳トンネルのインバート変状に着目した地 山評価と対応策, 土木学会第 70 回年次学術講演会 III-116, pp. 231-232, 2015.

2) 三浦貴幸，柿崎昌志，湊敦之，田湯正孝 : 開業直前に インバート盤ぶくれ対策を施工, トンネルと地下, Vol. 46, No. 6, pp. 7-16, 2015.

3) 丸山勝, 中野清人, 天野淨行, 下村哲雄: 61 日間連 続車線規制によるインバート再構築工事一上信越自 動車道日暮山トンネルー, トンネルと地下, Vol. 44, No. 12,pp. 17-28, 2013

4) 久保原猛, 若林秀明, 鈴木延彰, 齋藤貴 : 供用中の卜 ンネルで未収束路盤隆起に挑む一北陸新幹線一ノ瀬 トンネルほかー, トンネルと地下, Vol. 45, No. 9, pp. 45-53, 2014.

5) 小林寛明, 井浦智実, 上野光, 渡辺和之, 嶋本敬介,
土木学会論文集F1 (トンネル工学), Vol. 75, No. 1, 116-129, 2019.

伊藤直樹 : 山岳トンネルの盤ぶくれとその対策に関す る基礎的研究, 土木学会論文集 F1 (トンネル工学), Vol. 71, No. 3 (特集号), pp. 80-93, 2015.

6) 小林寛明, 下津達也, 上野光, 渡辺和之, 嶋本敬介, 朝倉俊弘 : 長期的な盤ぶくれに対するインバート構造 の抑制効果に関する基礎的研究，土木学会論文集 F1 (トンネル工学), Vol. 72, No. 3 (特集号), pp. 96-107, 2016.

7) 嶋本敬介, 野城一栄, 小島芳之, 塚田和彦, 朝倉俊弘 : 地山の吸水膨張による山岳トンネルの地盤隆起現象 とその対策工に関する研究，土木学会論文集 F1（ト ンネル工学), Vol. 68, No. 3, pp. 65-79, 2012.

8) 嶋本敬介, 野城一栄, 小島芳之, 中西祐介, 塚田和彦, 朝倉俊弘 : 地山の塑性化に伴う山岳トンネルの路盤隆 起現象とその対策工に関寸る研究，土木学会論文集 F1 (トンネル工学), Vol. 69, No. 1, pp. 54-72, 2013.

9) 土木学会 : トンネル標準示方書 (山岳編) ・同解説, 1977.

10) 日本鉄道建設公団：NATM 設計施工指針（案），1983.

11）渡邊康夫, 藍郷一博, 鈴木尊 : 供用中の新幹線トンネ ルで発生した路盤隆起の原因とその対策, トンネルと 地下, Vol. 38, No. 9, pp. 7-16, 2007.

12）独立行政法人鉄道建設・運輸施設整備支援機構: 山岳 トンネル設計施工標準・同解説， 2008 .

13）東日本高速道路株式会社，中日本高速道路株式会社， 西日本高速道路株式会社 : 設計要領第三集トンネル編, 2015.

14）独立行政法人鉄道建設・運輸施設整備支援機構 : 地質 調查標準示方書, p. 56, 2019.

15）桜井孝, 立松英信, 水野清: 膨張性粘土鉱物の簡易定 量法の研究，鉄道技術研究報告，No. 1312, 1986.

16) 土木学会: トンネルライブラリー第 25 号 山岳トンネ ルのインバート, 2013.

17) 中野清人, 小川澄, 楠本太, 樽井稔: 早期閉合トンネ ルの現状と挙動分析, トンネル工学報告集, 第 20 巻, pp. 151-162, 2010.

18）佐久間智, 菅原徳夫, 多田誠, 遠藤祐司：供用中に発 生した急激な盤ぶくれ变状を復旧する，トンネルと地 下, Vol. 40, No. 12, pp. 27-37, 2009.

19）野城一栄, 橘直毅, 小島芳之, 野々村政一, 朝倉俊弘 : 地震による変位を想定したトンネルの模型実験，トン ネル工学報告集, 第 17 巻, pp. 195-202, 2007.

20) 嶋本敬介, 川越健, 石田良二: 地圧による変状トンネ ルの岩石の吸水膨張特性に関する一考察, 第 51 回地 盤工学研究発表会, G-05, pp. 1481-1482, 2016.

21）川越健, 嶋本敬介, 野城一栄: 泥質岩中の割れ目密集 部がトンネルの変状に与える影響の検討, 第 44 回岩 盤力学に関寸るシンポジウム講演集, No. 53, pp. 295-300, 2016.

22）原田哲夫, 副田孝一, 出光隆, 渡辺明: 静的破砕凨の 膨張圧測定法と膨張圧の諸性質, 土木学会論文集, No. 478/V-21, pp. 91-100, 1993.

23）財団法人鉄道総合技術研究所: 都市部鉄道構造物の近 接施工対策マニュアル，2007.

24) ITSCA Consulting Group, Inc.: FLAC ${ }^{3 \mathrm{D}}$ Version 4.0 Theory and Background, 2009.

25) 新井泰, 有賀貴志, 平野勝識, 渡辺忠朋 : 鉄筋腐食之 断面欠損による RC はりの曲げ挙動に関する解析的研 究, コンクリート工学年次論文集, Vol. 29, No. 3, pp. 169-174, 2007. 
26）野城一栄, 小島芳之, 新井泰, 岡野法之, 竹村次朗 : 圧縮破壊後の軟化を考慮した無筋コンクリート山岳 トンネル覆工の数值解析手法に関する研究, 土木学会 論文集 C, Vol. 65, No. 4, pp. 1024-1038, 2009.

27) 中岡健一, 畑浩二, 木梨秀雄 : 盤膨れに着目した山岳 トンネルの長期挙動解析，トンネル工学報告集，第 26 巻, I-32, 2016.

28）アイダンオメール，赤木知之，伊東孝，川本眺万：ス クイーズィング地山におけるトンネルの変形挙動と その予測方法について，土木学会論文集，No. 448/III-19, pp. 73-82, 1992.

\section{INHIBITION EFFECT OF A NEW SHAPE INVERT THAT PREVENTS FLOOR HEAVING AFTER COMPLETION}

\section{Hiroaki KOBAYASHI, Hikaru UENO, Atsumi ISOGAI, Keisuke SHIMAMOTO and Kiyoshi KISHIDA}

Recently, many cases have been reported in which mountain tunnels have been occurred floor heaving after completion and countermeasures were forced. In particular, since the floor heaving is a problem directly related to the running safety of the train, invert is the most important structure and it is difficult to permit large displacements resulting from floor heaving. However, it is not easy to adopt invert with a large curvature or reinforced concrete structure for all grounds where floor heaving is concerned from the ground condition during excavation from the viewpoint of workability and economy. For this reason, it has been desired to provide an invert structure which is relatively easy to construct, capable of flexibly coping with on-site and economical, and having a high effect of inhibiting the floor heaving. In this research, we performed a model experiment and numerical analysis on the new shape invert structure devised to solve these problems, grasp the behavior of it, compare it with the standard invert structure, verified the inhibitory effect. 